\title{
Supplementation of prepartum dairy cows with $\beta$-carotene
}

\author{
R. C. Oliveira, ${ }^{*}$ B. M. Guerreiro, $†$ N. N. Morais Junior, ${ }^{*}$ R. L. Araujo, ${ }^{*}$ R. A. N. Pereira, $\ddagger$ and M. N. Pereira*1 \\ *Departamento de Zootecnia, Universidade Federal de Lavras, 37200-000, Lavras, Brazil \\ †Departamento de Reprodução Animal, Universidade de São Paulo, 05508-270, São Paulo, Brazil \\ ‡Empresa de Pesquisa Agropecuária de Minas Gerais, 37200-000, Lavras, Brazil
}

\begin{abstract}
The prepartum supplementation of dairy cows with $\beta$-carotene was evaluated. Cows were blocked by parity and expected calving date and assigned to a treatment: $\beta$-carotene ( $1.2 \mathrm{~g} / \mathrm{cow}$ per d) or control (no supplementation). The same total mixed ration batch was offered to all cows, and $\beta$-carotene was top dressed to individual cows once per day. The data set contained 283 Holsteins that received a treatment for $>14 \mathrm{~d}$ $(29.1 \pm 6.9 \mathrm{~d})$. Frequency distributions were analyzed with the GENMOD procedure of SAS using logistic regression for binomial data. Continuous variables were analyzed with the MIXED procedure of SAS. Within parity, nonparametric estimates of the survivor function for reproductive variables were computed using the product-limit method of the Kaplan-Meier method with the LIFETEST procedure of SAS. Plasma $\beta$-carotene concentration before supplementation was similar between supplemented and nonsupplemented cows (2.99 $\mu \mathrm{g} / \mathrm{mL}$ ) and peaked at $3.26 \pm 0.175 \mu \mathrm{g} / \mathrm{mL}$ on $\mathrm{d}-15$ \pm 2.4 precalving for supplemented cows $(2.62 \pm 0.168$ $\mu \mathrm{g} / \mathrm{mL}$ for control). Colostrum density, milk yield, and milk composition were similar between treatments. $\beta$-Carotene tended to increase milk protein content from 2.90 to $2.96 \%$ and to decrease the proportion of primiparous cows with a milk fat to protein ratio $>1.5$ from 22.6 to $6.4 \%$. The proportion of primiparous and multiparous cows with difficult calving, metritis, progesterone $>1 \mathrm{ng} / \mathrm{mL}$ at $21 \mathrm{~d}$ and at $42 \mathrm{~d}$ in lactation, $\%$ conception at first service, and \% pregnancy at 90 and $150 \mathrm{~d}$ in lactation were similar between treatments. A trend for decreased incidence of somatic cell count $>200,000$ cells $/ \mathrm{mL}$ was present in multiparous cows supplemented with $\beta$-carotene (38.9\% vs. $28.1 \%)$. Betacarotene was associated with a reduction in the proportion of multiparous cows with retained placenta $12 \mathrm{~h}$ postpartum from 29.9 to $21.7 \%$; time of placenta release
\end{abstract}

Received October 29, 2014

Accepted June 7, 2015.

${ }^{1}$ Corresponding author: mpereira@dzo.ufla.br was $392 \mathrm{~min}$ (340 to 440) for $\beta$-carotene and $490 \mathrm{~min}$ (395 to 540) for control (median and 95\% confidence interval). For primiparous cows, placenta release was not affected by $\beta$-carotene (incidence was $15.4 \%$ ). The intervals from calving to first estrus, to first service, and to conception were not affected by $\beta$-carotene supplementation in either parity. However, independent of treatment, cows with improved reproductive efficiency had increased postpartum $\beta$-carotene concentration in plasma. The prepartum supplementation of $\beta$-carotene increased plasma concentration around calving. No response in milk yield or reproductive performance was detected. $\beta$-Carotene supplementation was associated with a lower incidence of retained placenta in multiparous cows.

Key words: $\beta$-carotene, retained placenta, transition period

\section{INTRODUCTION}

Carotenoids, such as $\beta$-carotene, can be converted to vitamin $\mathrm{A}$ in cells of the intestinal mucosa, liver, uterus, and ovaries (Chew et al., 1982a; Borel et al., 2005; Morales et al., 2006). Carotenoids also have antioxidant function, protecting cells and cell components against reactive oxygen species (Chew and Park, 2004). The antioxidant defense system of periparturient dairy cows may be overloaded with reactive oxygen species, predisposing animals to immune-system-related diseases, such as retained placenta, metritis, and mastitis (Bernabucci et al., 2002; LeBlanc et al., 2004; Castillo et al., 2005). $\beta$-Carotene supplementation increased the proliferative response of lymphocytes to mitogens and enhanced the phagocytic ability of polymorphonuclear neutrophils (Tjoelker et al., 1988; Michal et al., 1994). $\beta$-Carotene deficiency can affect reproduction, lactation performance, and health negatively, justifying its supplementation to dairy cows around calving.

In confinement dairy production systems, total farm reliance on preserved forages is not uncommon. The carotenoid content of forages is reduced during storage as silage or hay (Chauveau-Duriot et al., 2005), and the content in grains is low (Holden et al., 1999). 
Positive responses in dairy cow fertility and lactation performance have been observed when $\beta$-carotene was supplemented after calving (Aréchiga et al., 1998; De Ondarza et al., 2009), although absent (Bindas et al., 1984; Akordor et al., 1986) or negative (Folman et al., 1987) effects on reproduction have been reported. Kaewlamun et al. (2011) and Wang et al. (2013) have reported benefits in uterine health of cows supplemented with $\beta$-carotene before calving. Kawashima et al. (2009) also showed in a retrospective study that ovulatory cows during the first follicular wave postpartum had higher plasma $\beta$-carotene concentration before calving than anovulatory cows. These studies suggest that $\beta$-carotene supplementation before calving may improve fertility in early lactation.

In small confinement systems adopting multiple diets, it is not uncommon for fresh cows to go directly to the most nutrient-dense diet of the farm without having access to a postcalving-specific diet. The permanence time of cows in postcalving groups is also variable, depending on herd management practices and degree of overcrowding. This scenario makes the adoption of nutrition strategies specifically focused on the transition period, usually defined as the period between $3 \mathrm{wk}$ before and 3 wk after parturition (Drackley, 1999), difficult. Thus, the aim of this study was to evaluate the effect of $\beta$-carotene supplementation only during the prepartum transition period on lactation performance, reproduction, and health of early lactation dairy cows.

\section{MATERIALS AND METHODS}

Experimental procedures were approved by the Federal University of Lavras Bioethic Committee in Utilization of Animals (protocol no. 056/13). The study was conducted in a commercial dairy herd in southeast Brazil. The farm housed primiparous and multiparous cows in separate free-stall pens during the prefresh period and during lactation. The prefresh cow barn with headlocks was split into 2 halves with more stalls than cows. One load of TMR was offered twice daily to all 4 groups of cows. Within parity, cows were blocked based on expected calving date and were randomly assigned to a treatment at $\mathrm{d}-25$ to -31 of the predicted calving date (goal was a 28-d prepartum transition period). Cows were moved from the far off dry cow diet to the prefresh cow diet once per week. Treatments were 1.2 $\mathrm{g} / \mathrm{d}$ of $\beta$-carotene $(12 \mathrm{~g} / \mathrm{d}$ of Rovimix, containing $10 \%$ $\beta$-carotene, DSM Nutritional Products, São Paulo, Brazil) or control. Beta-carotene was mixed with a cup of ground corn and top dressed to individual treatment cows on the feed offered in the morning, and control cows received nothing. The intake of $\beta$-carotene was observed visually. Cows were moved to individual ma- ternity pens when signs of calving were observed, and treatment allocation was maintained until the day of parturition.

For the 283 cows (66 primiparous and 217 multiparous) that received the treatments for $14 \mathrm{~d}$ or more and that had available data for at least one variable, the duration of the precalving transition period was $29.1 \pm$ $6.9 \mathrm{~d}$. The number of cows for each variable is described in Table 1. The period from the beginning of treatment allocations until the day the last cow completed 150 DIM lasted from February 7 to September 27, 2012. Parturitions occurred from February 21 to April 30.

The composition of the diets were defined by the manager without the interference of the research team. The diet for the prepartum transition period contained (\% of DM) $55.9 \%$ corn silage, $17.2 \%$ green chop Tifton grass (Cynodon spp.), $8.9 \%$ soybean meal, $3.9 \%$ finely ground corn, $6.4 \%$ citrus pulp, $4.8 \%$ whole cottonseed, and $2.9 \%$ minerals, vitamins, and additives (18.7\% live yeast, $12.4 \%$ urea, $5.0 \%$ Mycofix, $0.5 \%$ Sel-Plex, and $63.4 \%$ of a product containing $5 \% \mathrm{Ca}, 1 \% \mathrm{P}, 1 \% \mathrm{Mg}$, $1 \% \mathrm{Na}, 1.15 \% \mathrm{Cl}, 0.8 \% \mathrm{~S}, 39.3 \mathrm{mg} / \mathrm{kg} \mathrm{Co}, 660 \mathrm{mg} /$ $\mathrm{kg} \mathrm{Cu}, 775 \mathrm{mg} / \mathrm{kg} \mathrm{Fe}, 19.5 \mathrm{mg} / \mathrm{kg} \mathrm{I}, 1,630 \mathrm{mg} / \mathrm{kg} \mathrm{Mn}$, $8.98 \mathrm{mg} / \mathrm{kg} \mathrm{Se}, 2,368 \mathrm{mg} / \mathrm{kg} \mathrm{Zn}, 260 \mathrm{kIU} / \mathrm{kg}$ of vitamin A, $35 \mathrm{kIU} / \mathrm{kg}$ of vitamin $\mathrm{D}, 2,600 \mathrm{IU} / \mathrm{kg}$ of vitamin $\mathrm{E}$, and $100 \mathrm{mg} / \mathrm{kg}$ biotin). The lactating cow diet contained (\% of DM) $34.8 \%$ corn silage, $8.4 \%$ green chop Tifton grass, $13.8 \%$ soybean meal, $6.1 \%$ whole heated soybeans, $18.6 \%$ finely ground corn, $11.9 \%$ citrus pulp, $2.3 \%$ whole cottonseed, and $4.1 \%$ minerals, vitamins, and additives (18.1\% Megalac-E, $15.8 \%$ limestone, $6.8 \%$ sodium bicarbonate, $3.4 \%$ live yeast, $2.7 \% \mathrm{NaCl}$, $1.1 \%$ Mycofix, $0.2 \%$ Sel-Plex, and $51.9 \%$ of a product containing $21 \% \mathrm{Ca}, 15 \% \mathrm{P}, 3 \% \mathrm{Mg}, 3 \% \mathrm{~S}, 100 \mathrm{mg} /$ $\mathrm{kg} \mathrm{Co}, 3,000 \mathrm{mg} / \mathrm{kg} \mathrm{Cu}, 180 \mathrm{mg} / \mathrm{kg} \mathrm{I}, 5,000 \mathrm{mg} / \mathrm{kg}$ $\mathrm{Mn}, 80 \mathrm{mg} / \mathrm{kg} \mathrm{Se}, 12,000 \mathrm{mg} / \mathrm{kg} \mathrm{Zn}, 1,000 \mathrm{kIU} / \mathrm{kg}$ of vitamin $\mathrm{A}, 250 \mathrm{kIU} / \mathrm{kg}$ of vitamin $\mathrm{D}$, and $3,250 \mathrm{IU} / \mathrm{kg}$ of vitamin $\mathrm{E}$ ).

Blood samples from the coccygeal vessels were obtained on the first day of supplementation (d -29 , $29.1 \pm 6.9 \mathrm{~d}$ prepartum), between $\mathrm{d}-18$ and -10 relative to calving $(\mathrm{d}-15,15.0 \pm 2.4 \mathrm{~d}$ prepartum), and on $\mathrm{d} 7$ and $\mathrm{d} 56$ of lactation. Blood $\beta$-carotene content was quantified as in Schweigert et al. (2007): a single-step denaturation and $\beta$-carotene extraction into organic solvent, followed by $\beta$-carotene measurement using iCheck, a portable spectrophotometer (BioAnalyt GmbH, Teltow, Germany). Blood concentrations were classified as high $(\geq 3.5 \mu \mathrm{g} / \mathrm{mL})$, intermediate $(\geq 2$ to $<3.5 \mu \mathrm{g} / \mathrm{mL})$, or low $(<2 \mu \mathrm{g} / \mathrm{mL}$; Schweigert and Immig, 2007).

Blood serum progesterone (P4) concentration was analyzed in samples from the coccygeal vessels obtained on d 21 and 42 of lactation. Serum was stored 
Table 1. Number of observations used for analysis of response variables on treatments control and $\beta$-carotene, for primiparous and multiparous cows

\begin{tabular}{|c|c|c|c|c|}
\hline \multirow[b]{2}{*}{ Item } & \multicolumn{2}{|c|}{ Control } & \multicolumn{2}{|c|}{$\beta$-carotene } \\
\hline & Primiparous & Multiparous & Primiparous & Multiparous \\
\hline Calving to first estrus & 33 & 97 & 33 & 91 \\
\hline Calving to first service & 31 & 94 & 29 & 87 \\
\hline Calving to conception & 31 & 94 & 29 & 87 \\
\hline Colostrum density & 31 & 95 & 26 & 97 \\
\hline Conception at first service & 30 & 84 & 28 & 74 \\
\hline Day of peak & 30 & 69 & 29 & 70 \\
\hline Difficult calvings & 32 & 107 & 33 & 106 \\
\hline Linear SCC & 33 & 95 & 32 & 89 \\
\hline Mastitis & 33 & 95 & 32 & 89 \\
\hline Metritis & 31 & 94 & 31 & 87 \\
\hline Milk & 30 & 69 & 29 & 70 \\
\hline Milk $\%$ fat $/ \%$ protein & 31 & 89 & 31 & 84 \\
\hline Milk fat $\%$ & 31 & 89 & 31 & 84 \\
\hline Milk protein \% & 31 & 89 & 31 & 84 \\
\hline $\mathrm{P} 4^{1}>1 \mathrm{ng} / \mathrm{mL}$ at $21 \mathrm{DIM}$ & 23 & 86 & 29 & 83 \\
\hline $\mathrm{P} 4>1 \mathrm{ng} / \mathrm{mL}$ at $42 \mathrm{DIM}$ & 28 & 83 & 31 & 78 \\
\hline Peak & 30 & 69 & 29 & 70 \\
\hline Blood $\beta$-carotene d -29 & 33 & 109 & 33 & 108 \\
\hline Blood $\beta$-carotene $\mathrm{d}-15$ & 20 & 41 & 18 & 46 \\
\hline Blood $\beta$-carotene d 7 & 30 & 95 & 32 & 103 \\
\hline Blood $\beta$-carotene d 56 & 29 & 75 & 31 & 73 \\
\hline Pregnancy at 150 DIM & 33 & 95 & 33 & 87 \\
\hline Pregnancy at 90 DIM & 33 & 98 & 33 & 91 \\
\hline Time of placenta release & 32 & 107 & 33 & 106 \\
\hline
\end{tabular}

${ }^{1} \mathrm{P} 4=$ progesterone.

at $-20^{\circ} \mathrm{C}$ until assayed for $\mathrm{P} 4$ concentration by solid phase RIA using a Coat-A-Count Progesterone kit (Diagnostic Products Corporation, Los Angeles, CA). The intraassay coefficients of variation for P4 assays were 0.14 and $1.68 \%$, for low and high samples, and the interassay coefficients of variation were 9.93 and $2.12 \%$, for low and high samples, respectively. Cows with luteal activity on the day of sampling were defined as serum progesterone concentration above $1 \mathrm{ng} / \mathrm{mL}$.

Immediately before the expected calving date, cows were moved to sand-bedded maternity pens. Calving was classified by farm personnel as unassisted or assisted (manual extraction by 1 or 2 farm employees with or without assistance of a veterinarian). Neither cesarean section nor fetotomy were performed. The incidence of twins was $1.06 \%$ of parturitions in both treatments. Colostrum density was determined with a thermo lactodensimeter (Incoterm, Porto Alegre, Brazil) at $20^{\circ} \mathrm{C}$. The time between postpartum placenta release (min) and calf delivery was recorded up to 12 $\mathrm{h}$. The fetal membranes still attached after $12 \mathrm{~h}$ were considered retained placenta.

Cows were milked 3 times per d starting at 0400, 1200 , and $2000 \mathrm{~h}$. Milk yield of each cow was recorded daily from 20 to 109 DIM, and one sample was obtained between 15 and 42 DIM $(30.1 \pm 8.3)$. Milk samples were preserved in 2-bromo-2-nitropropane-1,3-diol, and the concentrations of solids and SCC were measured by infrared analysis (Bentley 2000, Bentley Instruments Inc., Chaska, MN). Milk fat to protein ratio greater than 1.5 was considered a predictor of ketosis (Heuer et al., 1999). A SCC greater than 200,000 cells $/ \mathrm{mL}$ was considered as mastitis. The SCC was converted to a linear scale from 0 to 9 (linear SCC), the midpoint of each score represented by the following linear SCC values $(\times 1,000$ cells $/ \mathrm{mL}): 12.5$ for linear SCC 0,25 for SCC linear, 50 for linear SCC 2, 100 for linear SCC 3, 200 for linear SCC 4, 400 for linear SCC 5, 800 for linear SCC 6, 1,600 for linear SCC 7, 3,200 for linear SCC 8, and 6,400 for linear SCC 9.

Cows were kept under routine herd reproductive management practices. Transrectal ultrasonography (Aloka SSD 500, 5-MHz linear transducer, Tokyo, Japan) of all cows was performed by the herd veterinarian at $35.1 \pm 4.3$ DIM. Cows were then examined by transrectal ultrasonography at 2-wk intervals and received prostaglandin $\mathrm{F}_{2 \alpha}$ (500 $\mu \mathrm{g}$ of cloprostenol, i.m.; Ciosin, Schering-Plough, Cotia, Brazil) when a corpus luteum was detected or GnRH (100 $\mu \mathrm{g}$ of Fertagyl, i.m.; Schering-Plough) when a follicle $>10 \mathrm{~mm}$ was detected, until insemination after a 60 -d voluntary waiting period. Purulent secretion or presence of liquid in the uterus was defined as metritis. Estrus detection was performed visually twice per day for $1 \mathrm{~h}$. Inseminations 
were performed $12 \mathrm{~h}$ after the manifestation of the first signs of natural or prostaglandin $\mathrm{F}_{2 \alpha}$-induced estrus. Pregnancy diagnosis by ultrasonography was performed from d 25 to 38 after insemination, and confirmation was performed $14 \mathrm{~d}$ later.

\section{Statistical Analyses}

Continuous variables were analyzed with the MIXED procedure of SAS (SAS Institute Inc., Cary, NC) with a model containing the fixed effects of parity (primiparous cows, multiparous cows), block within parity, treatment (control, $\beta$-carotene), and the interaction of parity and treatment. Frequency distributions were analyzed with the GENMOD procedure of SAS using logistic regression for binomial data. Within parity, nonparametric estimates of the survivor function for variables calving to first estrus, calving to first service, calving to conception, and time of placenta release were computed using the product-limit method of the Kaplan-Meier method, by the LIFETEST procedure of SAS. Survival curves were generated. Comparison of the survival curves between treatments used rank tests for homogeneity: log-rank and Wilcoxon test. Blood $\beta$-carotene concentration at 7 and 56 DIM was also analyzed with the MIXED procedure of SAS without taking treatment into account, with a model containing the fixed effects of event (difficult calving, retained placenta, milk fat to protein ratio, metritis, mastitis, P4 at 21 DIM, P4 at 42 DIM, conception at first service, pregnancy at 90 DIM, and pregnancy at 150 DIM), sampling day ( 7 and 56
DIM), and the interaction of event and sampling day. Statistical significance, trends, and weak trends were considered at $P \leq 0.05, P>0.05$ to $P \leq 0.10$, and $P>$ 0.10 to $P \leq 0.15$, respectively.

\section{RESULTS}

The blood concentration of $\beta$-carotene at the start of the prepartum transition period $(\mathrm{d}-29)$ was similar between treatments (Tables 2 and 3). Blood concentration of $\beta$-carotene for control cows was lower on $\mathrm{d}$ -15 than on $\mathrm{d}-29$ relative to calving, whereas it was higher for the $\beta$-carotene-supplemented cows (Table 3 ). Blood $\beta$-carotene concentration of supplemented cows peaked at $3.3 \mu \mathrm{g} / \mathrm{mL}$ on $\mathrm{d}-15$. Blood concentrations were lowest in both treatments immediately after calving, although they were increased by supplementation. Primiparous cows had lower blood $\beta$-carotene concentration than multiparous cows only at d -29 (Table $3)$. The prepartum supplementation of $\beta$-carotene increased $\beta$-carotene concentration in blood around calving, but the difference between treatments decreased with advanced DIM.

No evidence was observed for positive responses to $\beta$-carotene supplementation in colostrum density, milk yield, and milk fat concentration (Table 4). However, $\beta$-carotene supplementation tended to increase milk protein concentration. A trend was observed for a decreased proportion of primiparous cows with a milk fat to protein ratio greater than 1.5 when $\beta$-carotene was supplemented (Table 5). A weak trend was observed

Table 2. Proportion of cows with blood $\beta$-carotene content high $(\geq 3.5 \mu \mathrm{g} / \mathrm{mL})$, intermediate $(\geq 2$ to $<3.5 \mu \mathrm{g} / \mathrm{mL})$, or low $(<2 \mu \mathrm{g} / \mathrm{mL})$ at $\mathrm{d}$ -29 and -15 prepartum, and at $\mathrm{d} 7$ and 56 postpartum, on control or $\beta$-carotene treatments

\begin{tabular}{|c|c|c|c|c|c|c|c|c|}
\hline Item & Control & $\beta$-carotene & $\mathrm{Est}^{1}$ & $\mathrm{SE}^{2}$ & Odds ratio & \multicolumn{2}{|c|}{$95 \% \mathrm{CI}^{3}$} & $P$-value \\
\hline \multicolumn{9}{|l|}{ Day $-29^{4}$} \\
\hline High & 28.2 & 29.1 & -0.04 & 0.26 & 0.96 & 0.57 & 1.60 & 0.87 \\
\hline Intermediate & 66.9 & 64.5 & 0.10 & 0.25 & 1.11 & 0.68 & 1.81 & 0.68 \\
\hline Low & 4.9 & 6.4 & -0.27 & 0.52 & 0.76 & 0.27 & 2.10 & 0.60 \\
\hline \multicolumn{9}{|l|}{ Day $-15^{5}$} \\
\hline High & 4.92 & 48.4 & -2.93 & 0.65 & 0.05 & 0.02 & 0.19 & $<0.01$ \\
\hline Intermediate & 49.2 & 45.3 & 0.83 & 0.37 & 1.17 & 0.58 & 2.36 & 0.02 \\
\hline Low & 45.9 & 6.3 & 2.68 & 0.59 & 12.72 & 4.11 & 39.42 & $<0.01$ \\
\hline \multicolumn{9}{|l|}{ Day 7} \\
\hline High & 0.8 & 5.2 & -1.91 & 1.08 & 0.15 & 0.02 & 1.22 & 0.08 \\
\hline Intermediate & 23.2 & 45.9 & -1.03 & 0.27 & 0.36 & 0.21 & 0.61 & $<0.01$ \\
\hline Low & 76.0 & 48.9 & 1.20 & 0.27 & 3.31 & 1.95 & 5.63 & $<0.01$ \\
\hline \multicolumn{9}{|l|}{ Day 56} \\
\hline High & 3.8 & 9.6 & -0.98 & 0.61 & 0.38 & 0.11 & 1.24 & 0.11 \\
\hline Intermediate & 59.6 & 63.5 & -0.16 & 0.29 & 0.85 & 0.48 & 1.48 & 0.57 \\
\hline Low & 36.5 & 26.9 & 0.45 & 0.30 & 1.56 & 0.87 & 2.81 & 0.14 \\
\hline
\end{tabular}

${ }^{1}$ Parameter estimate generated with the GENMOD procedure of SAS using logistic regression for binomial data. Control is zero.

${ }^{2}$ Standard error of the estimate.

${ }^{3}$ Profile likelihood $95 \%$ confidence intervals for odds ratio.

${ }^{4} 29.1 \pm 6.9$ d prepartum.

${ }^{5} 15.0 \pm 2.4 \mathrm{~d}$ prepartum. 
Table 3. Blood $\beta$-carotene content $(\mu \mathrm{g} / \mathrm{mL})$ at $\mathrm{d}-29$ and -15 prepartum, and at $\mathrm{d} 7$ and 56 postpartum, for primiparous (Prim) and multiparous (Mult) cows on control or $\beta$-carotene treatments

\begin{tabular}{|c|c|c|c|c|c|c|c|c|}
\hline \multirow[b]{2}{*}{ Item } & \multicolumn{2}{|c|}{ Control } & \multicolumn{2}{|c|}{$\beta$-carotene } & \multirow[b]{2}{*}{ SEM } & \multicolumn{3}{|c|}{$P$-value ${ }^{1}$} \\
\hline & Prim & Mult & Prim & Mult & & Par & Treat & Par $\times$ Treat \\
\hline Day $-29^{2}$ & 2.71 & 3.33 & 2.73 & 3.19 & 0.113 & 0.01 & 0.59 & 0.52 \\
\hline Day $-15^{3}$ & 2.51 & 2.73 & 3.19 & 3.33 & 0.283 & 0.51 & $<0.01$ & 0.71 \\
\hline Day 7 & 1.55 & 1.71 & 2.02 & 2.08 & 0.104 & 0.32 & $<0.01$ & 0.64 \\
\hline Day 56 & 2.26 & 2.29 & 2.38 & 2.54 & 0.094 & 0.30 & 0.06 & 0.50 \\
\hline
\end{tabular}

${ }^{1}$ Effects of parity (Par), treatment (Treat), and the interaction of Par and Treat.

${ }^{2} 29.1 \pm 6.9$ d prepartum.

${ }^{3} 15.0 \pm 2.4 \mathrm{~d}$ prepartum

Table 4. Milk somatic cell count, colostrum density, and milk yield and solids content for primiparous (Prim) and multiparous (Mult) cows on control of $\beta$-carotene treatments

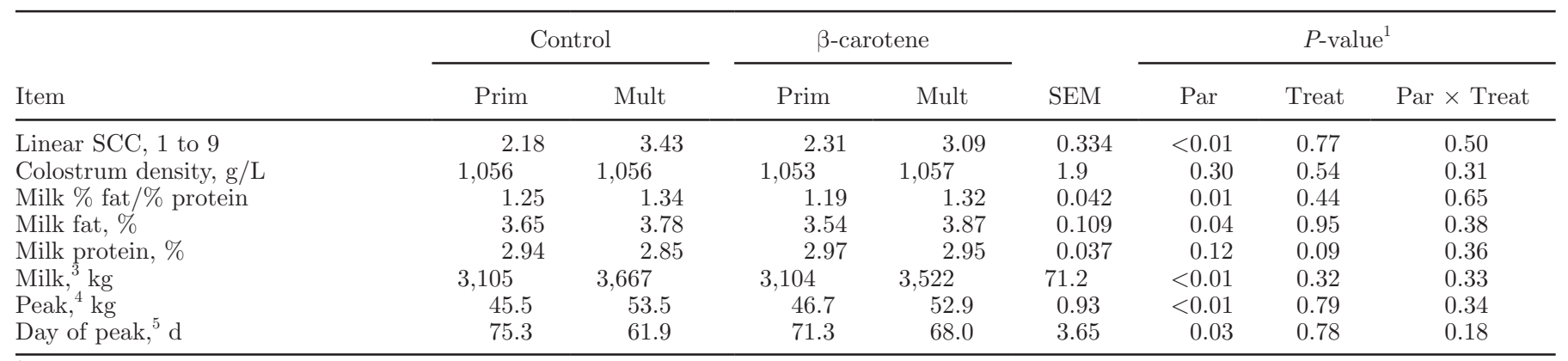

${ }^{1}$ Effects of parity (Par), treatment (Treat) and the interaction of Par and Treat.

${ }^{2}$ Milk yield from d 20 to 109 of lactation.

${ }^{3}$ Maximum daily yield.

${ }^{4}$ Day postpartum of maximum yield.

Table 5. Proportion of health and reproductive events for primiparous cows on control of $\beta$-carotene treatments

\begin{tabular}{|c|c|c|c|c|c|c|c|c|}
\hline $\begin{array}{l}\text { Item } \\
\text { Difficult calvings, \% }\end{array}$ & $\frac{\text { Control }}{18.8}$ & $\frac{\beta \text {-carotene }}{24.2}$ & $\frac{\text { Est }^{1}}{-0.33}$ & $\frac{\mathrm{SE}^{2}}{0.61}$ & $\frac{\text { Odds ratio }}{0.72}$ & \multicolumn{2}{|c|}{$95 \% \mathrm{CI}^{3}$} & $\frac{P \text {-value }}{0.59}$ \\
\hline Mastitis, ${ }^{4} \%$ & 12.1 & 15.6 & -0.29 & 0.72 & 0.74 & 0.18 & 3.07 & 0.68 \\
\hline Metritis, $\%$ & 6.5 & 9.7 & -0.44 & 0.95 & 0.64 & 0.10 & 4.15 & 0.64 \\
\hline $\mathrm{P} 4>1 \mathrm{ng} / \mathrm{mL}$ at $21 \mathrm{DIM}^{7} \%$ & 21.7 & 13.8 & 0.55 & 0.74 & 1.74 & 0.41 & 7.38 & 0.46 \\
\hline $\mathrm{P} 4>1 \mathrm{ng} / \mathrm{mL}$ at $42 \mathrm{DIM}^{7} \%$ & 35.7 & 29.0 & 0.31 & 0.56 & 1.36 & 0.45 & 4.06 & 0.58 \\
\hline Conception at first service, $\%$ & 50.0 & 42.9 & 0.29 & 0.53 & 1.33 & 0.47 & 3.76 & 0.59 \\
\hline
\end{tabular}

${ }^{1}$ Parameter estimate generated with the GENMOD procedure of SAS using logistic regression for binomial data. Control is zero.

${ }^{2}$ Standard error of the estimate.

${ }^{3}$ Profile likelihood $95 \%$ confidence interval for odds ratio.

${ }^{4}$ Cows with SCC $>200,000 / \mathrm{mL}$ at first test $30.1 \pm 8.3$ DIM.

${ }^{5}$ Purulent secretion or presence of liquid in uterus at ultrasound exam $40.8 \pm 9.7$ DIM.

${ }^{6}$ Ratio of milk fat content to milk protein content at first test $31.3 \pm 9.6$ DIM.

${ }^{7}$ Blood progesterone (P4) content $>1 \mathrm{ng} / \mathrm{mL}$ at 21 and 42 DIM.

${ }^{8}$ Cows pregnant at 90 and 150 DIM. 
Table 6. Proportion of health and reproductive events for multiparous cows on control of $\beta$-carotene treatments

\begin{tabular}{|c|c|c|c|c|c|c|c|c|}
\hline$\frac{\text { Item }}{\text { Difficult calvings, } \%}$ & $\frac{\text { Control }}{25.2}$ & $\frac{\beta \text {-carotene }}{18.9}$ & $\frac{\mathrm{Est}^{1}}{0.37}$ & $\frac{\mathrm{SE}^{2}}{0.33}$ & $\frac{\text { Odds ratio }}{1.45}$ & \multicolumn{2}{|c|}{$95 \% \mathrm{CI}^{3}$} & $\frac{P \text {-value }}{0.26}$ \\
\hline Mastitis, ${ }^{4} \%$ & 38.9 & 28.1 & 0.49 & 0.32 & 1.63 & 0.88 & 3.03 & 0.12 \\
\hline Metritis, $\%$ & 31.9 & 35.6 & -0.17 & 0.31 & 0.85 & 0.46 & 1.57 & 0.60 \\
\hline $\mathrm{P} 4>1 \mathrm{ng} / \mathrm{mL}$ at $21 \mathrm{DIM}_{-}^{7} \%$ & 17.4 & 25.3 & -0.47 & 0.38 & 0.62 & 0.29 & 1.31 & 0.21 \\
\hline $\mathrm{P} 4>1 \mathrm{ng} / \mathrm{mL}$ at $42 \mathrm{DIM}^{7} \%$ & 33.7 & 38.5 & -0.21 & 0.33 & 0.81 & 0.43 & 1.55 & 0.53 \\
\hline Conception at first service, $\%$ & 27.4 & 33.8 & -0.30 & 0.35 & 0.74 & 0.37 & 1.46 & 0.38 \\
\hline
\end{tabular}

${ }^{1}$ Parameter estimate generated with the GENMOD procedure of SAS using logistic regression for binomial data. Control is zero.

${ }^{2}$ Standard error of the estimate.

${ }^{3}$ Profile likelihood $95 \%$ confidence interval for odds ratio.

${ }^{4}$ Cows with $\mathrm{SCC}>200,000 / \mathrm{mL}$ at first test $27.3 \pm 8.1 \mathrm{DIM}$.

${ }^{5}$ Purulent secretion or presence of liquid in uterus at ultrasound exam $39.7 \pm 8.5$ DIM.

${ }^{6}$ Ratio of milk fat content to milk protein content at first test 29.6 \pm 8.3 DIM.

${ }^{7}$ Blood progesterone (P4) content $>1 \mathrm{ng} / \mathrm{mL}$ at 21 and 42 DIM.

${ }^{8}$ Cows pregnant at 90 and 150 DIM.

for a reduction in the incidence of SCC greater than 200,000 cells/mL in multiparous cows supplemented with $\beta$-carotene (Table 6).

The supplementation of $\beta$-carotene was associated with a reduction in the time of placenta release for multiparous cows (Figure 1), which reduced the proportion of cows with retained placenta $12 \mathrm{~h}$ postcalving from 29.9 to $21.7 \%$. For primiparous cows, in which the proportion of cows with retained placenta was $15.4 \%$ across both treatments, $\beta$-carotene supplementation did not affect placenta release (Figure 2).

The supplementation of $\beta$-carotene did not affect the proportion of cows pregnant at first service, at 90

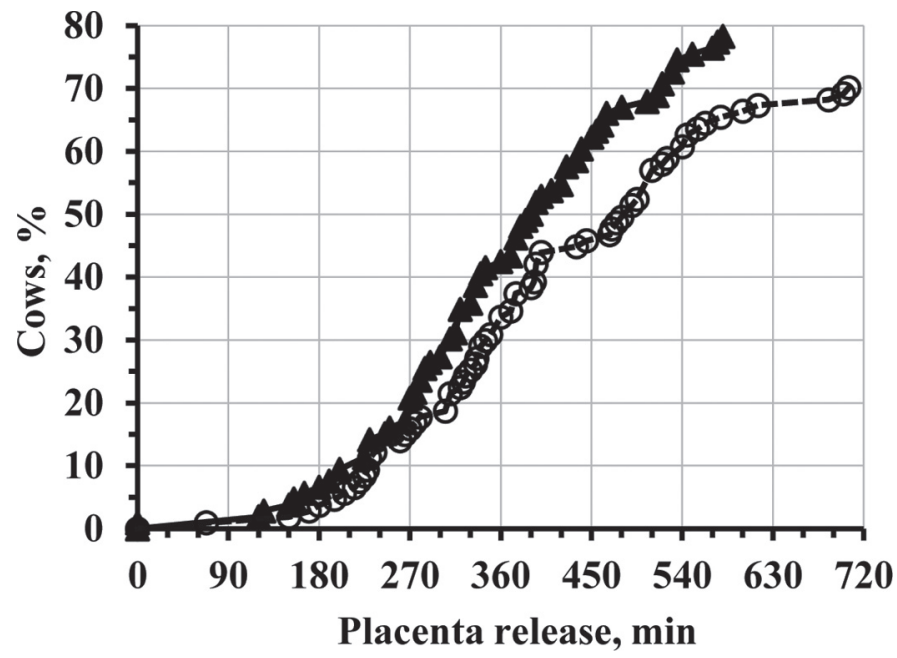

Figure 1. Survival curve for time postcalving of placenta release for multiparous cows on control $(\bigcirc, \mathrm{n}=107)$ or $\beta$-carotene $(\boldsymbol{\Lambda}, \mathrm{n}=$ $106)$ treatments. Median and $95 \%$ confidence interval were $392 \mathrm{~min}$ (340 to 440) for $\beta$-carotene and $490 \mathrm{~min}$ (395 to 540) for control. LogRank $P=0.05$, and Wilcoxon $P=0.04$. and 150 DIM, or the proportion of cows with serum progesterone content above $1 \mathrm{ng} / \mathrm{mL}$ at 21 and $42 \mathrm{DIM}$ (Tables 5 and 6 ). In addition, no response was observed in the intervals from calving to first estrus (Figures 3 and 4) or from calving to conception (Figures 5 and 6). An unexpected trend was found for multiparous cows supplemented with $\beta$-carotene to have an extended calving to first service interval (Figure 7), but this interval was similar between supplemented and nonsupplemented primiparous cows (Figure 8).

Independent of supplementation, blood $\beta$-carotene concentration postpartum was higher in cows that had improved reproduction and decreased mastitis

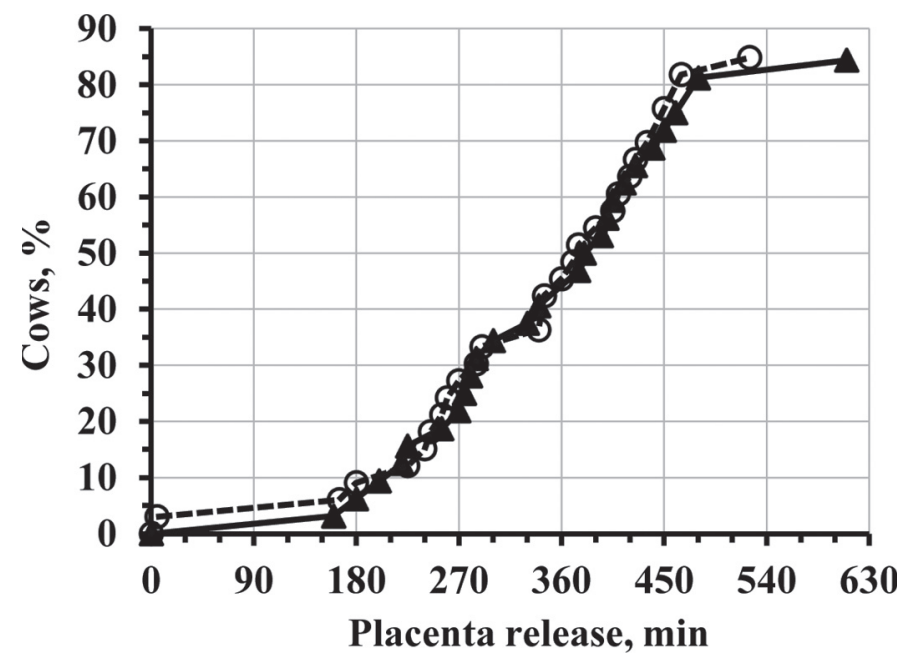

Figure 2. Survival curve for time postcalving of placenta release for primiparous cows on control $(\bigcirc, \mathrm{n}=33)$ or $\beta$-carotene $(\boldsymbol{\Lambda}, \mathrm{n}=33)$ treatments. Median and $95 \%$ confidence interval were 388 min (285 to 440) for $\beta$-carotene and 375 min (290 to 425) for control. LogRank $P$ $=0.87$, and Wilcoxon $P=0.86$. 


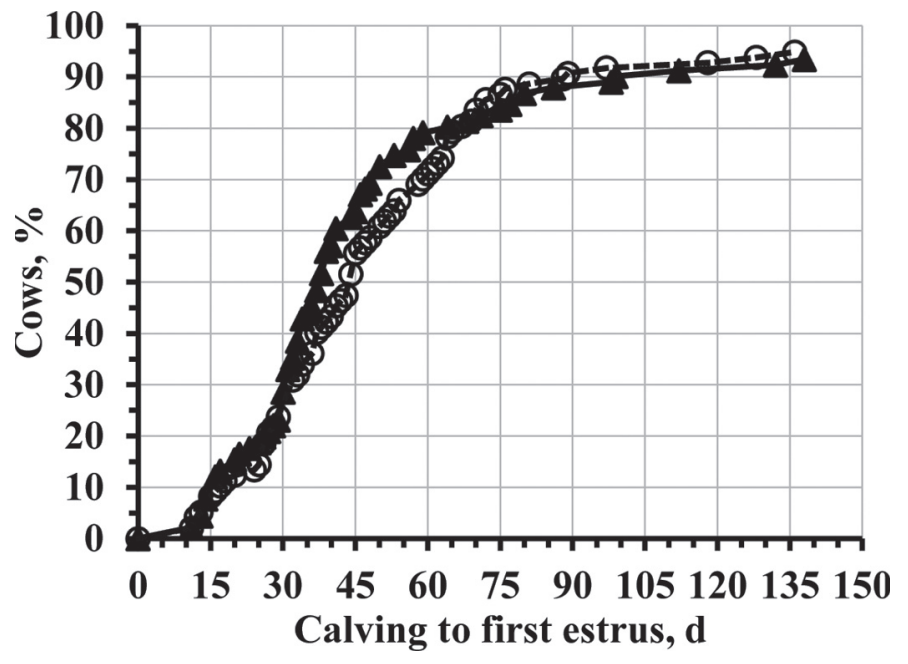

Figure 3. Survival curve for calving to first estrus for multiparous cows on control $(\bigcirc, \mathrm{n}=97)$ or $\beta$-carotene $(\boldsymbol{\Lambda}, \mathrm{n}=91)$ treatments. Median and 95\% confidence interval were $38 \mathrm{~d}$ (34 to 43 ) for $\beta$-carotene and $44 \mathrm{~d}$ (37 to 50) for control. LogRank $P=0.55$, and Wilcoxon $P=0.23$

(Table 7). A trend was also present for increased blood $\beta$-carotene concentration in cows with milk fat to protein ratio greater than 1.5 , and cows with serum progesterone greater than $1 \mathrm{ng} / \mathrm{mL}$ at 21 and $42 \mathrm{DIM}$ (Table 7). The relationship between these variables and blood $\beta$-carotene concentration was consistent across sampling days, and no treatment by day interaction was detected. No difference in blood $\beta$-carotene concentration postpartum was detected for cows with or

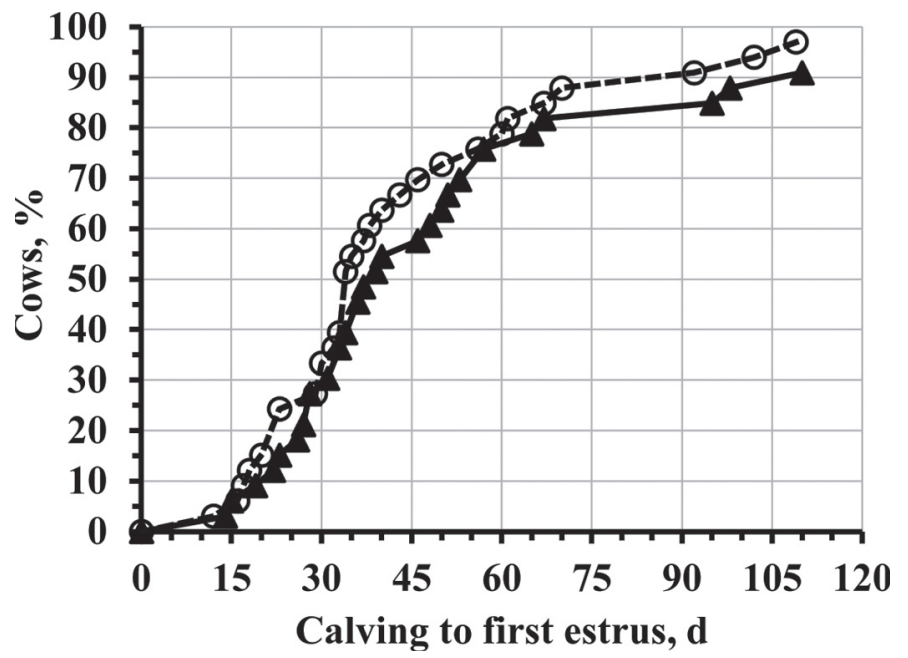

Figure 4. Survival curve for calving to first estrus for primiparous cows on control $(\bigcirc, \mathrm{n}=33)$ or $\beta$-carotene $(\boldsymbol{\Lambda}, \mathrm{n}=33)$ treatments. Median and $95 \%$ confidence interval were $39 \mathrm{~d}$ (33 to 51) for $\beta$-carotene and $34 \mathrm{~d}$ (30 to 43) for control. LogRank $P=0.34$, and Wilcoxon $P=0.42$.

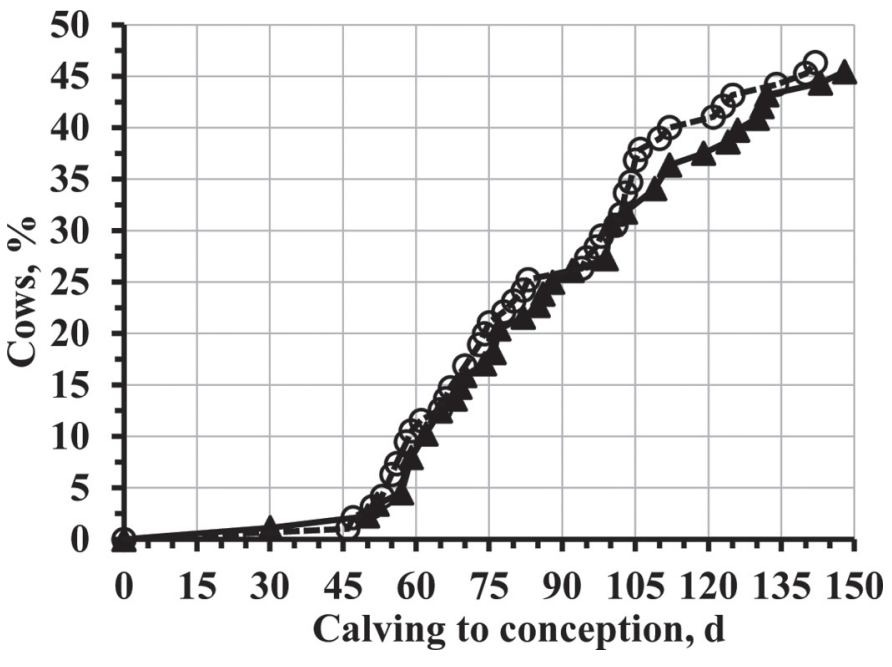

Figure 5. Survival curve for calving to conception for multiparous cows on control $(\bigcirc, \mathrm{n}=94)$ or $\beta$-carotene $(\boldsymbol{\Lambda}, \mathrm{n}=87)$ treatments. LogRank $P=0.82$, and Wilcoxon $P=0.75$.

without retained placenta, metritis, or difficult calving (Table 7).

\section{DISCUSSION}

The lower concentration of $\beta$-carotene in blood at $\mathrm{d}$ -29 for primiparous compared with multiparous cows suggests that heifers were more deficient in this compound than lactating cows. The farm routinely used some green chop Tifton grass as a source of long fiber for lactating cows $(8.4 \%$ of diet DM during the ex-

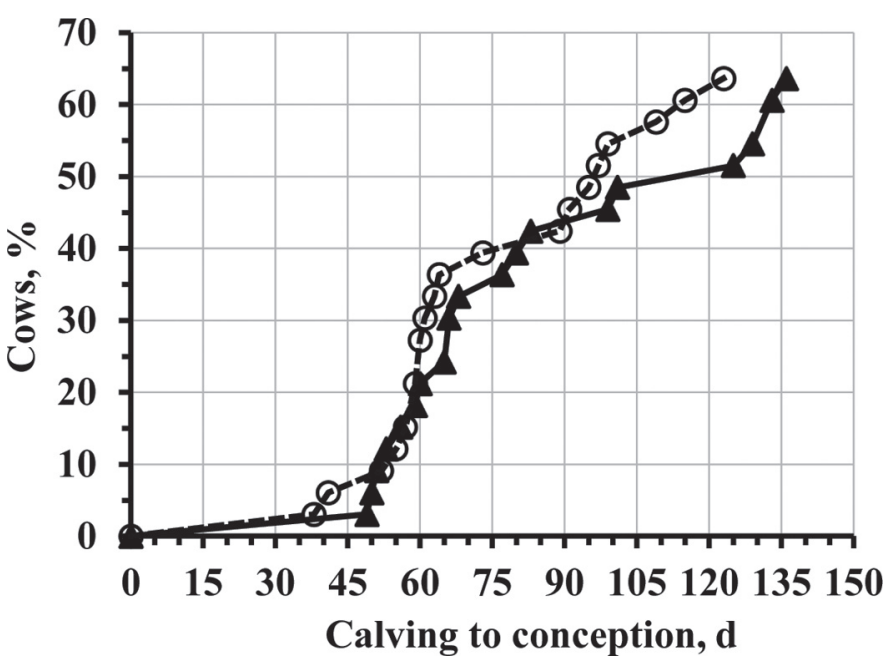

Figure 6. Survival curve for calving to conception for primiparous cows on control $(\mathrm{O}, \mathrm{n}=31)$ or $\beta$-carotene $(\boldsymbol{\Lambda}, \mathrm{n}=29)$ treatments. Median was $125 \mathrm{~d}$ for $\beta$-carotene and $97 \mathrm{~d}$ for control. LogRank $P=$ 0.77 , and Wilcoxon $P=0.65$. 


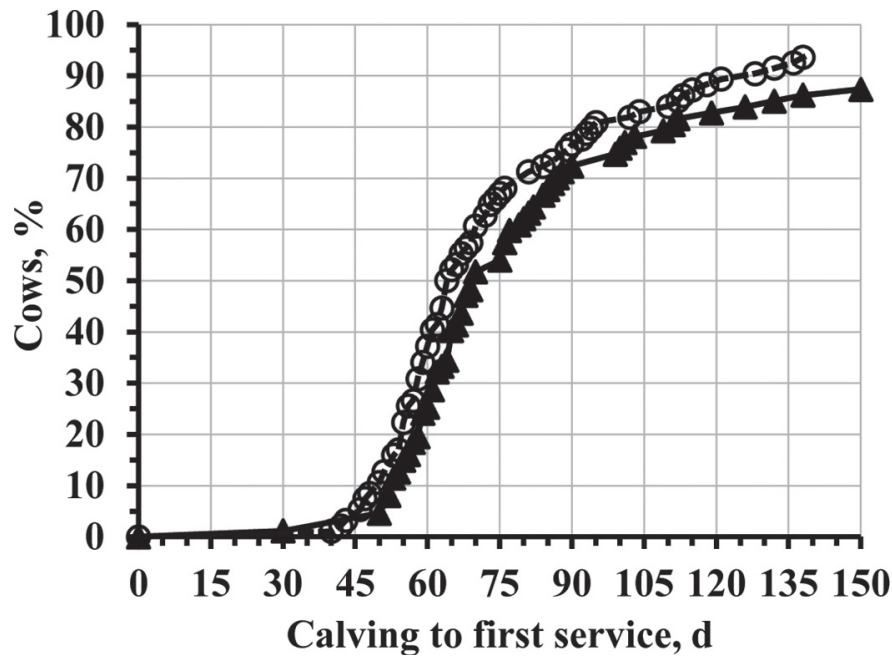

Figure 7. Survival curve for calving to first service for multiparous cows on control $(O, \mathrm{n}=94)$ or $\beta$-carotene $(\mathbf{\Lambda}, \mathrm{n}=87)$ treatments. Median and $95 \%$ confidence interval were $70 \mathrm{~d}$ (65 to 79 ) for $\beta$-carotene and $64 \mathrm{~d}$ (61 to 70 ) for control. LogRank $P=0.09$, and Wilcoxon $P=0.07$.

periment), whereas heifers were fed on corn or sorghum silages as the only forage source before the prepartum transition period. Beta-carotene deficiency may be an issue not only for lactating cows, but also for heifers. Although parity had an effect on blood $\beta$-carotene content before supplementation begun prepartum, content at d -29 was similar between supplemented and nonsupplemented cows. Parturition apparently eliminated the parity effect on blood $\beta$-carotene concentration at calving. The blood $\beta$-carotene concentration being lowest shortly after calving (d 7) is in agreement with other reports (Folman et al., 1987; Kaewlamun et al.,

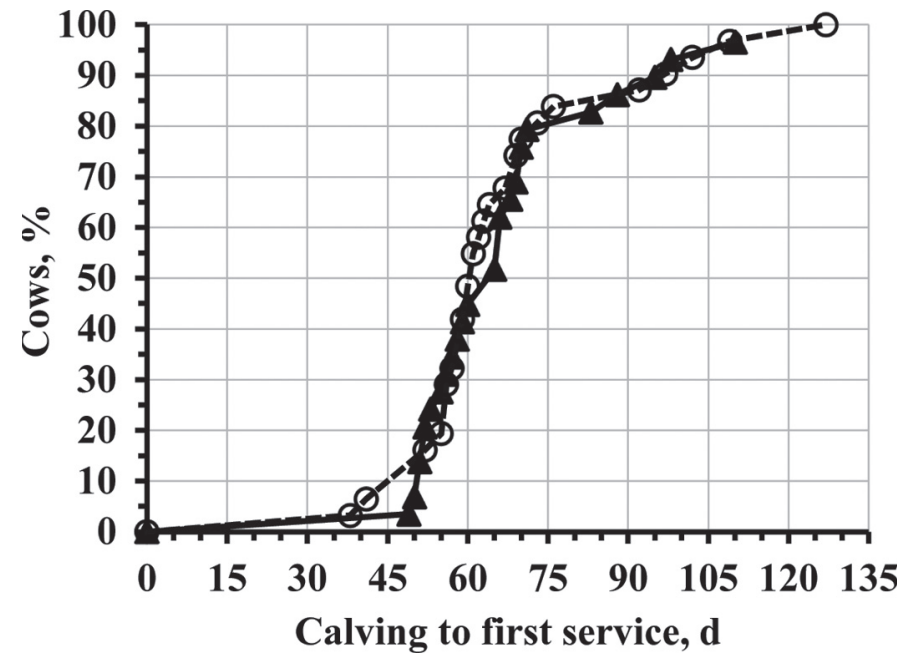

Figure 8. Survival curve for calving to first service for primiparous cows on control $(O, \mathrm{n}=31)$ or $\beta$-carotene $(\boldsymbol{\Lambda}, \mathrm{n}=29)$ treatments. Median and 95\% confidence interval were $65 \mathrm{~d}$ (56 to 69$)$ for $\beta$-carotene and $61 \mathrm{~d}$ (57 to 67 ) for control. LogRank $P=0.73$, and Wilcoxon $P=0.87$.

2011). This has been attributed to the uptake of the compound by the mammary gland for colostrogenesis, especially during the last week of gestation (Johnston and Chew, 1984; Michal et al., 1994; Chawla and Kaur, 2004). The oxidation of $\beta$-carotene by an increased oxidative stress and the physiological decrease in DMI around calving may also contribute to a decreased blood $\beta$-carotene level (Goff et al., 2002).

Blood $\beta$-carotene concentration of supplemented cows peaked at $\mathrm{d}-15,2$ wk after the start of the supplementation. The mean concentration of $3.3 \mu \mathrm{g} / \mathrm{mL}$ $( \pm 0.17 \mathrm{SEM})$ for supplemented cows was lower than

Table 7. Blood $\beta$-carotene content $(\mu \mathrm{g} / \mathrm{mL})$ at 7 and $56 \mathrm{~d}$ postcalving according to events $(+=$ occurrence; $-=$ nonoccurrence $)$

\begin{tabular}{|c|c|c|c|c|c|c|c|c|}
\hline \multirow[b]{2}{*}{ Item } & \multicolumn{2}{|c|}{ Day 7} & \multicolumn{2}{|c|}{ Day 56} & \multirow[b]{2}{*}{ SEM } & \multicolumn{3}{|c|}{$P$-value } \\
\hline & + & - & + & - & & Event & Day & Event $\times$ day \\
\hline Difficult calvings & 1.84 & 1.93 & 2.42 & 2.39 & 0.083 & 0.48 & $<0.01$ & 0.36 \\
\hline Retained placenta & 1.87 & 1.90 & 2.33 & 2.38 & 0.082 & 0.66 & $<0.01$ & 0.92 \\
\hline Milk $\%$ fat $/ \%$ protein $>1.5^{1}$ & 1.96 & 1.90 & 2.55 & 2.31 & 0.091 & 0.13 & $<0.01$ & 0.37 \\
\hline Metritis $^{2}$ & 1.89 & 1.88 & 2.36 & 2.36 & 0.080 & 0.99 & $<0.01$ & 0.91 \\
\hline Mastitis $^{3}$ & 1.67 & 1.96 & 2.08 & 2.44 & 0.080 & $<0.01$ & $<0.01$ & 0.69 \\
\hline $\mathrm{P} 4>1 \mathrm{ng} / \mathrm{mL}$ at $21 \mathrm{DIM}^{4}$ & 2.14 & 1.84 & 2.39 & 2.34 & 0.092 & 0.07 & $<0.01$ & 0.20 \\
\hline $\mathrm{P} 4>1 \mathrm{ng} / \mathrm{mL}$ at $42 \mathrm{DIM}^{4}$ & 2.02 & 1.82 & 2.40 & 2.32 & 0.081 & 0.10 & $<0.01$ & 0.49 \\
\hline Conception at first service & 2.01 & 1.84 & 2.53 & 2.28 & 0.079 & 0.01 & $<0.01$ & 0.56 \\
\hline Pregnancy at $90 \mathrm{DIM}^{5}$ & 1.96 & 1.85 & 2.48 & 2.25 & 0.081 & 0.01 & $<0.01$ & 0.79 \\
\hline Pregnancy at 150 DIM $^{5}$ & 2.05 & 1.82 & 2.49 & 2.30 & 0.079 & 0.04 & $<0.01$ & 0.44 \\
\hline
\end{tabular}

${ }^{1}$ Ratio of milk fat content to milk protein content at first test $31.3 \pm 9.6$ DIM.

${ }^{2}$ Purulent secretion or presence of liquid in uterus at ultrasound exam 40.1 \pm 9.2 DIM.

${ }^{3}$ Cows with SCC $>200,000 / \mathrm{mL}$ at first test $29.1 \pm 8.3$ DIM.

${ }^{4}$ Blood progesterone $(\mathrm{P} 4)$ content $>1 \mathrm{ng} / \mathrm{mL}$ at 21 and 42 DIM.

${ }^{5}$ Cows pregnant at 90 and 150 DIM. 
the $7.5 \mu \mathrm{g} / \mathrm{mL} 2$ wk before calving of Kaewlamun et al. (2011). Those authors supplemented prepartum cows with $1 \mathrm{~g} / \mathrm{d}$ of $\beta$-carotene for $6 \mathrm{wk}$; blood $\beta$-carotene was $3 \mu \mathrm{g} / \mathrm{mL} 8 \mathrm{wk}$ before calving (at dry-off), and 6.5 $\mu \mathrm{g} / \mathrm{mL}$ with 2 wk of supplementation. The lower blood concentration value in our study may have been the result of a shorter duration of the supplementation period or of a supplementation period that was initiated closer to the active functioning of the mammary gland in preparation for the next lactation. However, blood $\beta$-carotene concentration was lowest immediately after calving in both experiments, although it was increased by the supplement in both experiments.

The supplementation of $\beta$-carotene before calving did not affect milk yield in early lactation in this experiment, similarly to the observations of others (Kaewlamun et al., 2012). However, Aréchiga et al. (1998) reported an increase in milk yield when cows under heat stress were supplemented with $\beta$-carotene from 15 to 170 DIM. Oldham et al. (1991) also observed a trend for increased milk yield when cows were supplemented with $\beta$-carotene from $-75 \mathrm{~d}$ prepartum to $42 \mathrm{~d}$ postpartum. These results suggest that to elicit a positive milk yield response to $\beta$-carotene, the supplementation may need to occur in early lactation. However, we observed a trend for increased milk protein concentration for cows supplemented with $\beta$-carotene, although the mechanism for this response cannot be elucidated based on our data.

The trend for decreased proportion of primiparous cows with a milk fat to protein ratio greater than 1.5 when $\beta$-carotene was fed, suggests that the supplement had a beneficial effect on the incidence of ketosis in first lactation cows (Heuer et al., 1999). Although previous studies have not detected differences in plasma NEFA and glucose in response to $\beta$-carotene supplementation before calving (Kawashima et al., 2010; Kaewlamun et al., 2012), the large numerical difference in the frequency of high milk fat to protein ratio between supplemented and nonsupplemented primiparous cows $(22.6 \%$ vs. 6.4\%) suggests that this finding may be worthy of further study. A weak trend for decreased proportion of multiparous cows with SCC greater than 200,000 cells/ $\mathrm{mL}$ in response to $\beta$-carotene supplementation was also observed. Bian et al. (2007) and Wang et al. (2013) also observed positive effects of $\beta$-carotene supplementation before calving on the incidence of mastitis in dairy cows. A possible mechanism for the beneficial effects of $\beta$-carotene on mastitis incidence may be related to its action as an antioxidant, leading to improved immune function (Tjoelker et al., 1988; Michal et al., 1994). A positive effect of the supplement on immune function is also indicated by the reduction in the time of placenta release in multiparous cows. Michal et al. (1994) observed that the supplementation of dairy cows with $\beta$-carotene before and after calving improved the phagocytic activity and killing ability of blood neutrophils and induced higher blood lymphocyte proliferation in response to mitogenic agents, which translated to a lower incidence of retained placenta and metritis.

Despite the reduction in placenta retention time, $\beta$-carotene supplementation did not affect uterine health or the DIM at postpartum ovulation. The precalving supplementation of $\beta$-carotene was only capable of affecting a response variable event occurring at calving (placenta release), or the therapeutic procedures adopted by the farm were capable of masking a supplementation effect on reproductive tract status. An increase in plasma hydroxyproline concentration, suggestive of a more complete uterine involution (Kaewlamun et al., 2011), and a decreased incidence of puerperal metritis in cows with retained placenta (Wang et al., 2013), have been reported in response to the prepartum supplementation of $\beta$-carotene.

The supplementation of $\beta$-carotene did not affect the intervals from calving to first estrus and from calving to conception, the proportion of cows pregnant at first service, at 90 and 150 DIM, and the proportion of cows with plasma progesterone content above $1 \mathrm{ng} / \mathrm{mL}$ at 21 and 42 DIM. The similarity in the duration of the interval from calving to first detected estrus suggests that the supplement did not induce advantages in estrous behavior. Kaewlamun et al. (2011) also did not detect a favorable response in reproductive performance of dairy cows to the prepartum supplementation of $\beta$-carotene. The supplementation of $\beta$-carotene postpartum may be required to elicit an increase in plasma levels in early lactation, possibly inducing a positive response in reproductive performance. The $\beta$-carotene has improved the pregnancy rate of dairy cows when it was supplemented for at least $90 \mathrm{~d}$ (Aréchiga et al., 1998) or 105 d (De Ondarza et al., 2009) postpartum.

Although no effect was detectable of the prepartum supplementation of $\beta$-carotene on conception rate, cows that conceived at first service and were pregnant at 90 and 150 DIM had higher blood $\beta$-carotene concentration postpartum than nonpregnant cows. Cows with serum progesterone content greater than $1 \mathrm{ng} / \mathrm{mL}$ at 21 and 42 DIM also had higher blood concentration of $\beta$-carotene than cows showing no luteal function. Kawashima et al. (2009) also showed a positive relationship between plasma $\beta$-carotene concentration before calving and ovulation in early lactation. Cows with low SCC had higher blood $\beta$-carotene concentration postpartum than cows with SCC higher than 200,000 cells $/ \mathrm{mL}$. In agreement with this finding, Chew et 
al. (1982b) reported a negative relationship between California Mastitis Test scores and plasma $\beta$-carotene concentration in dairy cows. These results suggest that $\beta$-carotene may have a role in immune-related diseases and fertility in dairy cows. High blood $\beta$-carotene concentration postpartum was also related to increased milk fat to protein ratio, suggesting that increased body fat mobilization increased $\beta$-carotene content in blood, probably as the result of $\beta$-carotene incorporation in triglycerides of bovine adipose tissue (Patterson, 1965; Arias et al., 2009).

\section{CONCLUSIONS}

The supplementation of $\beta$-carotene before calving increased blood concentration in periparturient dairy cows, but the difference in blood concentration between supplemented and nonsupplemented cows was reduced as DIM advanced. The prepartum supplementation of multiparous cows with $\beta$-carotene was associated with a lower incidence of retained placenta, but no responses were detectable in milk yield or reproductive performance.

\section{ACKNOWLEDGMENTS}

Authors are grateful to DSM Nutritional Products (São Paulo, Brazil), the Brazilian Federal Agency for Postgraduate Education (CAPES), and the Minas Gerais Foundation for Research Support (FAPEMIG) for funding this project; to the members of Grupo do Leite of the Federal University of Lavras, Bruno Gonzales and João Paulo Costa Gonçalves; to Cecília Rodrigues Alves Silveira from São Paulo State University (Jaboticabal, UNESP) for assistance during data collection; and to Kristina Weld from the University of Wisconsin-Madison for suggestions in text editing.

\section{REFERENCES}

Akordor, F. Y., J. B. Stone, J. S. Walton, K. E. Leslie, and J. G. Buchanan-Smith. 1986. Reproductive performance of lactating Holstein cows fed supplemental $\beta$-carotene. J. Dairy Sci. 69:21732178.

Aréchiga, C. F., C. R. Staples, L. R. McDowell, and P. J. Hansen. 1998. Effects of timed insemination and supplemental beta-carotene on reproduction and milk yield of dairy cows under heat stress. J. Dairy Sci. 81:390-402.

Arias, E., A. Gonza, A. Shimada, A. Varela-Echavarria, F. Ruiz-Lo, A. During, and O. Mora. 2009. $\beta$-Carotene is incorporated or mobilized along with triglycerides in bovine adipose tissue in response to insulin or epinephrine. J. Anim. Physiol. Anim. Nutr. (Berl.) 93:83-93.

Bernabucci, U., B. Ronchi, N. Lacetera, and A. Nardone. 2002. Markers of oxidative status in plasma and erythrocytes of transition dairy cows during hot season. J. Dairy Sci. 85:2173-2179.
Bian, S. B., R. Elliott, I. Immig, and D. F. Sun. 2007. The influence of beta-carotene supplementation on post-partum disease and subsequent reproductive performance of dairy cows in China. J. Anim. Feed Sci. 16(Suppl. 2):370-375.

Bindas, E. M., F. C. Gwazdauskas, R. J. Aiello, J. H. Herbein, M. L. McGilliard, and C. E. Polan. 1984. Reproductive and metabolic characteristics of dairy cattle supplemented with $\beta$-carotene. J. Dairy Sci. 67:1249-1255.

Borel, P., J. Drai, H. Faure, V. Fayol, C. Galabert, M. Laromiguiere, and G. Le Moel. 2005. Recent knowledge about intestinal absorption and cleavage of carotenoids. Ann. Biol. Clin. (Paris) 63:165-177.

Castillo, C., J. Hernandez, A. Bravo, M. Lopez-Alonso, V. Pereira, and J. L. Benedito. 2005. Oxidative status during late pregnancy and early lactation in dairy cows. Vet. J. 169:286-292.

Chauveau-Duriot, B., D. Thomas, J. Portelli, and M. Doreau. 2005. Carotenoids content in forages: Variation during conservation. Renc. Rech. Ruminants. 12:117.

Chawla, R., and H. Kaur. 2004. Plasma antioxidant vitamin status of periparturient cows supplemented with $\alpha$-tocopherol and 及-carotene. Anim. Feed Sci. Technol. 114:279-285.

Chew, B. P., L. L. Hollen, J. K. Hillers, and M. L. Herlugson. 1982b. Relationship between vitamin A and $\beta$-carotene in blood plasma and milk and mastitis in Holsteins. J. Dairy Sci. 65:2111-2118.

Chew, B. P., and J. S. Park. 2004. Carotenoid action on the immune response. J. Nutr. 134:257S-261S.

Chew, B. P., H. Rasmussen, M. H. Pubols, and R. L. Preston. 1982a. Effects of vitamin A and $\beta$-carotene on plasma progesterone and uterine protein secretions in gilts. Theriogenology 18:643-654.

De Ondarza, M. B., J. W. Wilson, and M. Engstrom. 2009. Case study: Effect of supplemental $\beta$-carotene on yield of milk and milk components and on reproduction of dairy cows. Prof. Anim. Sci. $25: 510-516$.

Drackley, J. K. 1999. Biology of dairy cows during the transition period: The final frontier? J. Dairy Sci. 82:2259-2273.

Folman, Y., I. Ascarelli, D. Kraus, and H. Barash. 1987. Adverse effect of $\beta$-carotene in diet on fertility of dairy cows. J. Dairy Sci. 70:357-366.

Goff, J. P., K. Kimura, and R. L. Horst. 2002. Effect of mastectomy on milk fever, energy, and vitamins $\mathrm{A}, \mathrm{E}$, and $\beta$-carotene status at parturition. J. Dairy Sci. 85:1427-1436.

Heuer, C., Y. H. Schukken, and P. Dobbelaar. 1999. Postpartum body condition score and results from the first test day milk as predictors of disease, fertility, yield, and culling in commercial dairy herds. J. Dairy Sci. 82:295-304.

Holden, J. M., A. L. Eldridge, G. R. Beecher, I. M. Buzzard, S. Bhagwat, C. S. Davis, L. W. Douglass, S. Gebhardt, D. Haytowitz, and S. Schakel. 1999. Carotenoid content of US foods: An update of the database. J. Food Compos. Anal. 12:169-196.

Johnston, L. A., and B. P. Chew. 1984. Peripartum changes of plasma and milk vitamin $\mathrm{A}$ and $\beta$-carotene among dairy cows with or without mastitis. J. Dairy Sci. 67:1832-1840.

Kaewlamun, W., M. Okouyi, P. Humblot, D. Remy, M. Techakumphu, C. Duvaux-Ponter, and A. A. Ponter. 2012. Effects of a dietary supplement of $\beta$-carotene given during the dry period on milk production and circulating hormones and metabolites in dairy cows. Rev. Med. Vet. (Toulouse) 163:235-241.

Kaewlamun, W., M. Okouyia, P. Humblot, M. Techakumphu, and A. A. Ponter. 2011. Does supplementing dairy cows with $\beta$-carotene during the dry period affect postpartum ovarian activity, progesterone, and cervical and uterine involution? Theriogenology 75:1029-1038.

Kawashima, C., K. Kida, F. J. Schweigert, and A. Miyamoto. 2009. Relationship between plasma carotene concentration during the peripartum period and ovulation of the first follicular wave postpartum in dairy cows. Anim. Reprod. Sci. 111:105-111.

Kawashima, C., S. Nagashima, K. Sawada, F. J. Schweigert, A. Miyamoto, and K. Kida. 2010. Effect of $\beta$-carotene supply during close-up dry period on the onset of first postpartum luteal activity in dairy cows. Reprod. Domest. Anim. 45:e282-e287. 
LeBlanc, S. J., T. H. Herdt, W. M. Seymour, T. F. Duffield, and K. E. Leslie. 2004. Peripartum serum vitamin E, retinol, and betacarotene in dairy cattle and their associations with disease. J. Dairy Sci. 87:609-619.

Michal, J. J., L. R. Heirman, T. S. Wong, B. P. Chew, M. Frigg, and L. Volker. 1994. Modulatory effects of dietary $\beta$-carotene on blood mammary leukocyte function in periparturient dairy cows. J. Dairy Sci. 77:1408-1421.

Morales, A., A. Rosas, A. González, A. Antaramian, A. Varela-Echavarría, A. Shimada, and O. Mora. 2006. Cloning of the bovine $\beta$-carotene-15, 15'-oxygenase and expression in gonadal tissues. Int. J. Vitam. Nutr. Res. 76:9-17.

Oldham, E. R., R. J. Eberhart, and L. D. Muller. 1991. Effects of supplemental vitamin A or $\beta$-carotene during the dry period and early lactation on udder health. J. Dairy Sci. 74:3775-3781.

Patterson, D. S. P. 1965. Plasma carotenoids and fat mobilization in stall-fed cattle. Nature 206:1069.

Schweigert, F. J., F. Engalbert, R. Mothes, A. Hurtienne, and I. Immig. 2007. Cooperative European study for the validation of a novel cow-side -carotene assay in serum and blood. Page 162 in Program of 13th Int. Conf. on Production Disease in Farm Animals, Leipzig, Germany.

Schweigert, F. J., and I. Immig. 2007. Rapid assessment of $\beta$-carotene status. Int. Dairy Top. 6:15-17.

Tjoelker, L. W., B. P Chew, T. S. Tanaka, and L. R. Daniel. 1988 Bovine vitamin A and $\beta$-carotene intake and lactational status. 1. Responsiveness of peripheral blood polymorphonuclear leukoytes to vitamin $\mathrm{A}$ and $\beta$-carotene challenge in vitro. J. Dairy Sci. 71:3112-3119.

Wang, D., M. Garcia, R. S. Bisinotto, N. Martinez, F. S. Lima, L. F. Greco, J. H. Shin, A. M. M. DiCalaça, A. L. Ranieri, B. L. Artiaga, E. K. Ganda, G. C. Gomes, L. F. V. Becker, S. C. Soares, V. S. Rezende, M. A. Engstrom, J. E. P. Santos, and C. R. Staples. 2013. Effect of supplementing vitamin $\mathrm{E}$ and $\beta$-carotene to prepartum Holstein cattle on health and reproductive responses. J. Dairy Sci. 96 (E-Suppl. 1):W76. (Abstr.) 